\title{
Membedah Konsep Ekonomi Islam
}

\author{
Oleh: Nur Kholis ${ }^{1}$
}

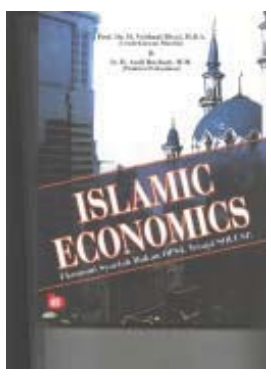

Judul : Islamic Economics Ekonomi Syariah bukan OPSI, Tetapi SOLUSI!

Penulis : Prof. Dr. H. Veithzal Rivai, MBA dan Ir. H. Andi Buchari, MM

Penerbit : Bumi Aksara

ISBN : 978-979-010-639-0

Terbit : September 2009

Tebal : xviii +574 halaman, $26 \mathrm{~cm}$

\section{Prolog}

Terbitnya buku yang berjudul Islamic Economic ini, semakin menambah literature yang membahas tentang ekonomi Islam dan ditulis oleh orang asli Indonesia. Secara kuantitatif, buku yang membahas ekonomi Islam dan ditulis oleh orang asli Indonesia masih sedikit. Uniknya buku ini, walaupun judul utamanya berbahasa Inggris, tetapi isinya berbahasa Indonesia. Penggunaan judul berbahasa Inggris ini mungkin memang terkait preferensi penulis dalam pemilihan judul, karena buku penulis sebelumnya juga diberi judul berbahasa Inggris walaupun isinya berbahasa Indonesia. 2

Umat Islam Indonesia khususnya, dan bangsa Indonesia pada umumnya memang patut bergembira, ketika sejak sekitar awal 1990-an dapat menyaksikan geliat sistem ekonomi Islam, atau sistem ekonomi syariah. Seperti nama yang melekat padanya ini, sistem ini dilandasi oleh nilai-nilai yang diajarkan oleh Islam.

\section{Ekonomi Islam, Konsep Baru?}

Kalau dirunut dalam sejarah, sesungguhnya telah sepuluh abad sebelum orang-orang Eropa menyusun teori-teori tentang ekonomi, telah diturunkan oleh Allah SWT di daerah Arab sebuah analisis tentang ekonomi yang unggul, karena

${ }^{1}$ Penulis adalah aktivis di Pusat Studi Islam, menyelesaikan pendidikan pascasarjana pada bidang ekonomi Islam di University of Malaya, Kuala Lumpur, tahun 2006.

${ }^{2}$ Misalnya Veithzal Rivai et. al., Bank and Financial Institution Management Conventional \& Sharia System. Jakarta: PT RajaGrafindo Persada, 2007. 
analisis ekonomi tersebut tidak hanya mencerminkan keadaan bangsa Arab pada waktu itu --sehingga hanya bermanfaat untuk bangsa Arab saat itu--, tetapi juga untuk seluruh dunia. Struktur ekonomi yang ada dalam firman Allah dan sudah sangat jelas aturan-aturannya tersebut, pernah dan telah dilaksanakan dengan baik oleh umat pada waktu itu. Sistem ekonomi tersebut adalah suatu susunan baru yang bersifat universal, bukan merupakan ekonomi nasional bangsa Arab. Sistem ekonomi tersebut dinamakan ekonomi Islam.

Ekonomi Islam pernah tidak populer sama sekali. Kepopuleran ekonomi Islam bisa dikatakan masih belum lama. Oleh karena itu, sering muncul pertanyaan, apakah ekonomi Islam adalah baru sama sekali? Jika melihat pada sejarah dan makna yang terkandung dalam ekonomi Islam, ia bukan sistem yang baru. Argumen untuk hal ini antara lain:

1. Islam sebagai agama samawi yang paling mutakhir adalah agama yang dijamin oleh Allah kesempurnaannya, seperti ditegaskan Allah dalam surat Al-Maidah (5): 3. Di sisi lain, Allah SWT juga telah menjamin kelengkapan isi Al-Qur'an sebagai petunjuk bagi umat manusia yang beriman dalam menjalankan perannya sebagai khalifah Allah di muka bumi. Hal ini ditegaskan Allah SWT dalam firmannya QS Al-An’am (6):38,

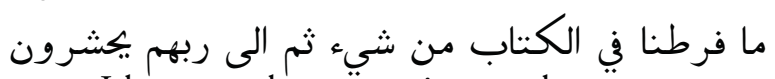

2. Sejarah mencatat bahwa umat Islam pernah mencapai zaman keemasan, yang tidak dapat disangkal siapapun. Dalam masa itu, sangat banyak kontribusi sarjana muslim yang tetap sangat diakui oleh semua pihak dalam berbagai bidang ilmu sampai saat ini, seperti matematika, astronomi, kimia, fisika, kedokteran, filsafat dan lain sebagainya. Sejarah juga membuktikan, bahwa sulit diterima akal sehat sebuah kemajuan umat dengan begitu banyak kontribusi dalam berbagai lapangan hidup dan bidang keilmuan tanpa didukung lebih awal dari kemajuan di lapangan ekonomi.

3. Sejarah juga mencatat banyak tokoh ekonom muslim yang hidup dan berjaya di zamannya masing-masing, seperti Tusi, Al-Farabi, Abu Yusuf, Ibnu Taimiyyah, Al-Maqrizi, Syah Waliyullah, Ibnu Khaldun dan lainlain.3 Bahkan yang disebut terakhir (Ibnu Khaldun) diakui oleh David Jean Boulakia4 sebagai berikut: "Ibn Khaldun discovered a great number of fundamental economic notions a few centuries before their official births. He discovered the virtues and the necessity of a division of labor before (Adam) Smith

3 M. Abdul Mannan, 1986, Islamic Economics, Theory and Practice. Cambride: Hodder and Stoughton, The Islamic Academy; M. Umar Chapra, 2001, What is Islamic Economics, Jeddah: IRTI - IDB, hal. 44.

${ }^{4}$ David Jean C. Boulakia, 1971, "Ibn Khaldun: A Fourteenth Century Economist", Journal of Political Economy, Vol. 79, No. 5 (September/October), The University of Chicago, hal. 1117-1118. 
and the principle of labor before Ricardo. He elaborated a theory of population before Malthus and insisted on the role of the state in the economy before Keynes. The economist who rediscovered mechanisms that he had already found are too many to be named." ". . . although Ibn Khaldun is the forerunner of many economist, he is an accident of history and has no consequence on the evolution of economic thought."

Ketiga argumen dan indikator di atas dapat dipakai sebagai pendukung yang amat meyakinkan bahwa sistem ekonomi Islam bukanlah hal baru sama sekali. Namun patut diakui bahwa sistem yang pernah berjaya ini pernah tenggelam dalam masa yang cukup lama, dan sempat dilupakan oleh sementara pihak, karena kuatnya dua sistem yang pernah berebut simpati dunia yaitu sistem kapitalisme dan sosialisme.

Sistem ekonomi Islam mengalami perkembangan sejarah baru pada era modern. Menurut Khurshid Ahmad, yang dikenal sebagai bapak Ekonomi Islam, ada empat tahapan perkembangan dalam wacana pemikiran ekonomi Islam, yaitu:

1. Tahapan Pertama, dimulai ketika sebagian ulama, yang tidak memiliki pendidikan formal dalam bidang ilmu ekonomi namun memiliki pemahaman terhadap persoalan-persoalan sosio-ekonomi pada masa itu, mencoba untuk menuntaskan persoalan bunga. Mereka berpendapat bahwa bunga bank itu haram dan kaum muslimin harus meninggalkan hubungan apapun dengan perbankan konvensional. Mereka mengundang para ekonom dan banker untuk saling bahu membahu mendirikan lembaga keuangan yang didasarkan pada prinsip-prinsip syariah dan bukan pada bunga. Yang menonjol dalam pendekatan ini adalah keyakinan yang begitu teguh haramnya bunga bank dan pengajuan alternatif. Masa ini dimulai kira-kira apada pertengahan dekade 1930-an dan mengalami puncak kemajuannya pada akhir dekade 1950-an dan awal dekade 1960-an. Pada masa itu di Pakistan didirikan bank Islam lokal ayang beroperasi bukan pada bunga. Sementara itu di Mesir juga didirikan lembaga keuangan yang beroperasi bukan pada bunga pada awal dasa warsa 1960-an. Lembaga keuangan ini diberi nama Mit Ghomir Local Saving yang berlokasi di delta sungai Nil, Mesir.

Tahapan ini memang masih bersifat prematur dan coba-coba sehingga dampaknya masih sangat terbatas. Meskipun demikian tahapan ini telah membuka pintu lebar bagi perkembangan selanjutnya.

2. Tahapan kedua dimulai pada akhir dasa warsa 1960-an. Pada tahapan ini para ekonom Muslim yang pada umumnya dididik dan dilatih di perguruan tinggi terkemuka di Amerika Serika dan Eropa mulai mencoba mengembangkan aspek-aspek tertentu dari sistem moneter Islam. Mereka melakukan analisis ekonomi terhadap larangan riba (bunga) dan mengajukan alternatif perbankan yang tidak berbasis bunga. Serangkaian konferensi dan seminar internasional tentang ekonomi dan keuangan Islam digelar 
beberapa kali dengan mengundang para pakar, ulama, ekonom baik muslim maupun non-muslim. Konferensi internasional pertama tentang ekonomi Islam digelar di Makkah al-Mukarromah pada tahun 1976 yang disusul kemudian dengan konferensi internasional tentang Islam dan Tata Ekonomi Internasional yang baru di London pada tahun 1977. Setelah itu digelar dua seminar tentang Ekonomi Moneter dan Fiskal dalam Islam di Makkah pada tahun 1978 dan di Islamabad pada tahun 1981. Kemudian diikuti lagi oleh konferensi tentang Perbankan Islam dan Strategi kerja sama ekonomi yang diadakan di Baden-Baden, Jerman pada tahun 1982 yang kemudian diikuti Konferensi Internasional Kedua tentang Ekonomi Islam di Islamabad pada tahun 1983.

Belasan buku dan monograf telah diterbitkan semenjak konferensi dan seminar ini digelar yang berhasil memberikan gambaran yang lebih terang tentang Ekonomi Islam baik dalam teori maupun praktek. Menurut Khurshid Ahmad, kontribusi yang paling signifikan selain dari hasil-hasil konferensi dan seminar tadi adalah laporan yang dikeluarkan oleh Dewan Ideologi Islam Pakistan tentang penghapusan riba dari ekonomi. Laporan ini tidak saja menjelaskan tentang hukum bunga bank yang telah ditegaskan haram oleh ijma' para ulama masa kini, tetapi juga memberikan pedoman bagaimana menghapuskan riba dari perekonomian.

Pada tahapan kedua ini muncul nama-nama ekonom muslim terkenal di seluruh dunia Islam anatara lain Prof. Dr. Khurshid Ahmad yang dinobatkan sebagai bapak ekonomi Islam, Dr. M. Umer Chapra, Dr. M. A. Mannan, Dr. Omar Zubair, Dr. Ahmad An-Najjar, Dr. M. Nejatullah Siddiqi, Dr. Fahim Khan, Dr. Munawar Iqbal, Dr. Muhammad Ariff, Dr. Anas Zarqa dan lainlain. Mereka adalah ekonom muslim yang dididik di Barat tetapi memahami sekali bahwa Islam sebagai way of life yang integral dan komprehensif memiliki sistem ekonomi tersendiri dan jika diterapkan dengan baik akan mampu membawa umat Islam kepada kedudukan yang berwibawa di mata dunia.

3. Tahapan ketiga ditandai dengan upaya-upaya konkrit untuk mengembangkan perbankan dan lembaga-lembaga keuangan non-riba baik dalam sektor swasta maupun dalam sektor pemerintah. Tahapan ini merupakan sinergi konkrit antara usaha intelektual dan material para ekonom, pakar, banker, para pengusaha dan para hartawan muslim yang memiliki kepedulian kepada perkembangan ekonomi Islam. Pada tahapan ini sudah mulai didirikan bankbank Islam dan lembaga investasi berbasis non-riba dengan konsep yang lebih jelas dan pemahaman ekonomi yang lebih mapan. Bank Islam yang pertama kali didirikan adalah Islamic Development Bank (IDB) pada tahun 1975 di Jeddah, Saudi Arabia. Bank Islam ini merupakan kerjasa sama antara negaranegara Islam yang tergabung dalam Organisasi Konferensi Islam (OKI). Tidak lama kemudian disusul oleh Dubai Islamic Bank. Setelah itu banyak sekali bank-bank Islam bermunculan di mayoritas negara-negara muslim termasuk 
di Indonesia.

4. Tahapan keempat ditandai dengan pengembangan pendekatan yang lebih integratif dan sophisticated untuk membangun keseluruhan teori dan praktek ekonomi Islam terutama lembaga keuangan dan perbankan yang menjadi indikator ekonomi umat.

\section{Ekonomi Islam di Indonesia}

Kemunculan kembali sistem ekonomi Islam, baik di tingkat dunia maupun Indonesia seperti yang kita saksikan sejak sekitar tiga atau empat dekade belakangan ini menimbulkan berbagai pandangan dan sikap. Ada yang menentangnya, ada yang skeptis, ada pula yang akomodatif, namun ada pula yang malah menerima dengan tangan terbuka.

Perkembangan gerakan ekonomi Islam di Indonesia kendati relatif terlambat dibanding beberapa negara lain, termasuk dari Jiran dekat kita Malaysia. Perbandingan perkembangan ekonomi Islam di Indonesia misalnya antara dekade 1980-an dan 2000-an sangat jauh berbeda, baik dalam tataran praktis, apalagi dalam tataran wacana. Ini tentu sangat patut di syukuri, betapapun perkembangan tersebut masih terus berlanjut dan hujan kritik terus mengucur dari banyak pihak dengan berbagai ragam pandangan dan latar belakangnya itu.

Dalam tataran wacana misalnya, istilah ekonomi Islam atau ekonomi syariah sudah sangat merata, hampir setiap orang pernah mengatakannya. Berbagai seminar, konferensi, workshop, dan simposium tentang ekonomi Islam sangat sering dilakukan dan dihadiri banyak peminat, baik di tingkat lokal, nasional, regional bahkan dunia. Kalau dulu rasanya sulit mencari sumber bacaan yang membahas persoalan ekonomi dari kacamata Islam, maka dewasa ini sangat banyak makalah, publikasi dalam bentuk jurnal bahkan buku teks yang membahas ekonomi Islam. tidak kurang bahkan beberapa media, baik dalam bentuk surat kabar, tabloid atau bahkan majalah yang sangat secara berkelanjutan mengangkat isu yang terkait dengan ekonomi Islam atau syariah. Perkembangan yang sama juga terjadi dalam dunia maya. Cukup banyak situs yang secara kontinyu dan sistematis menawarkan wacana ekonomi Islam.

Dalam tataran praktis, juga terlihat geliat yang sangat menggembirakan ketika bank atau lembaga keuangan Islam lahir, tumbuh dan bertambah hari demi hari, pekan demi pekan dan bulan demi bulan. Ketertarikan dan keterlibatan terhadap lembaga perbankan dan keuangan Islam tidak hanya ditunjukkan oleh lembaga swasta mikro sekelas koperasi tingkat desa, tetapi justru melibatkan otoritas moneter tertinggi di negeri ini, yakni Bank Sentral atau Bank Indonesia. Di lembaga yang disebut terakhir ini, sudah sejak beberapa tahun belakangan ini posisi unit yang mengatur segala sesuatu yang berkaitan dengan perbankan syariah ditempatkan di tingkat biro, dan bukan tidak mungkin seperti harapan banyak pihak. 
Selain itu, tumbuh dengan subur di seantero negeri berbagai kursus, sekolah atau bahkan perguruan tinggi yang membuka secara khusus pengajaran sistem ekonomi Islam ini, belum lagi puluhan atau mungkin mencapai ratusan lembaga studi atau penelitian yang mengkhususkan diri dalam pengkajian dan diseminasi ilmu ekonomi syariah atau yang terkait dengan itu.

Dalam tataran praktis, juga terlihat geliat yang sangat menggembirakan ketika bank atau lembaga keuangan Islam lahir, tumbuh dan bertambah hari demi hari, pekan demi pekan dan bulan demi bulan. Ketertarikan dan keterlibatan terhadap lembaga perbankan dan keuangan Islam tidak hanya ditunjukkan oleh lembaga swasta mikro sekelas koperasi tingkat desa, tetapi justru melibatkan otoritas moneter tertinggi di negeri ini, yakni Bank Sentral atau Bank Indonesia. Di lembaga yang disebut terakhir ini, sudah sejak beberapa tahun belakangan telah ada Direktorat Perbankan Syariah. Di samping itu, Departemen Keuangan (Depkeu) juga memutuskan untuk membentuk sub-direktorat asuransi syariah dan direktorat pembiayaan syariah. Hal ini dilakukan seiring pesatnya pertumbuhan industri asuransi syariah dan pembiayaan syariah di Indonesia sehingga perlu perhatian khusus pemerintah. Bahkan pemerintah juga telah mengundangkan UU tentang perbankan syariah, SBSN, dan lain-lain serta mengeluarkan PP yang mendukung perkembangan lembaga keuangan syariah.

\section{Isi Buku: at glance}

Buku ini membahas berbagai aspek tentang ekonomi Islam, di antaranya definisi ekonomi Islam, lingkungan ekonomi Islam, paradigm ekonomi Islam, tujuan ekonomi Islam, prinsip ekonomi Islam, system ekonomi Islam, system moneter Islam, hukum ekonomi Islam, konsep harta dan kepemilikan, keadilan redistribusi perekonomian dan lain-lain. Dalam buku ini juga dibahas tentang riba dan bunga, penanaman modal dan pengalokasian sumber daya dan kemudian melompat tentang pasar modal. Ketika membaca buku ini memang terkesan pembahasan agak terasa meloncat-loncat dan kurang begitu runtut.

Penulis buku ini menyatakan bahwa buku ini diperuntukkan untuk menjadi pegangan mahasiswa strata 1 dan strata 2, tetapi setelah mengkaji secara lebih mendalam isi dan format buku ini, Nampaknya buku ini hanya layak untuk strata 1 saja. Kenapa begitu? Beberapa catatan tentang hal itu dalam sub bab di bawah ini. Walaupun begitu, secara umum bisa dikatakan buku ini berkontribusi positif dalam mengisi masih langkanya literatur tentang ekonomi Islam berbahasa Indonesia yang ditulis oleh orang asli Indonesia.

\section{Menimbang Plus Minus Buku}

Sisi plus buku ini, sebagaimana telah disinggung dalam penjelasan di atas, mengisi keterbatasan buku-buku literature bagi perguruan tinggi serta bacaan 
yang bermakna bagi siapa saja yang ingin mengenal dan mendalami ekonomi Islam. Buku ini untuk pemula yang ingin tahu tentang ekonomi Islam memang cukup tepat, tetapi bagi orang yang sudah agak lama bersentuhan dengan ekonomi Islam, isi buku ini terasa kurang "menggigit."

Sedangkan sisi minus buku ini, kalau dicermati masih cukup banyak. Judul buku ini tidak konsisten dalam pemakaian istilah. Judul besar menggunakan istilah ekonomi Islam, tetapi dalam anak judul menggunakan istilah ekonomi syariah. Dalam level international, istilah yang dipakai dan popular adalah ekonomi Islam. Buku ini juga tidak mencantumkan foot note atau apapun rujukan dalam mengutip pendapat orang lain yang menjadi standar penulisan karya ilmiah. Hal ini tentu akan menyulitkan bagi pembaca untuk merunut lebih lanjut terkait dengan konten yang dibaca, selain mengabaikan hak dan penghargaan terhadap hasil karya orang lain yang dikutip. Jika ada orang yang kurang senang bisa menimbulkan tuduhan plagiasi.

Disamping itu buku ini juga tidak ada index-nya, sehingga menjadikan pembaca sulit melacak konsep-konsep penting yang terkait dalam halamanhalaman tertentu. Di sisi lain, buku ini juga tidak seragam dan terstandar dalam format babnya, ada bab yang ada pendahuluannya tetapi lebih banyak banyak yang tidak ada. Dalam sub bab ada pendahuluan tetapi tidak ada penutup atau kesimpulan. Susunan sub bab dalam setiap bab juga terasa kurang fokus dan kurang runtut, sehingga terkesan melompat dan keterkaitan antar sub bab menjadi kurang dekat. Ini berakibat agak menyulitkan bagi pembaca untuk menemukan poin inti dan penting dalam setiap pembahasan.

Dalam pembahasan buku ini, juga terdapat bab yang agak janggal, misalnya bab 8 , judulnya system moneter Islam, tetapi sub babnya yang hanya 3 termasuk pendahuluan tidak menunjukkan keterkaitan dengan judul besar. Judul sub babnya justru berbunyi: keniscayaan menuju kesejahteraan manusia dan asa ekonomi menurut Islam. Tidak ada satu sub bab pun yang terkait langsung dengan sistem moneter Islam. Terdapat juga bab yang sub babnya hanya dua buah termasuk pendahuluan. Bab seperti tentu terasa sangat janggal. Hal lain yang agak janggal juga, pada bab 15 dibahas tentang riba, tiba-tiba buku yang berjudul Islamic economics ini pada bab 16nya membahas tentang pasar modal.

Buku ini juga tidak menyertakan kesimpulan dalam setiap babnya sebagai ringkasan pokok terhadap materi yang telah dibahas. Mungkin penulis buku kesulitan membuat kesimpulan, karena memang pembahasan dalam setiap bab agak tidak runtut, sehingga menyulitkan merumuskan kesimpulan. Di samping itu, buku ini tidak mencantumkan pembahasan tentang produksi dan konsumsi, padahal topik tersebut biasanya selalu ada dalam pembahasan buku ekonomi.

Jika penulis buku menerbitkan buku ini bertujuan untuk mejadi buku pegangan kuliah (sebagaimana dikemukakan penulis di prakata), maka akan sangat bagus jika buku ini menyertakan pertanyaan-pertanyaan evaluasi dalam setiap babnya, agar mahasiswa dapat dengan mudah mengecek penguasaan terhadap materi yang telah dipelajari. 
Nur Kholis: Membedah Konsep Ekonomi Islam ...

\section{VI.Penutup}

Terlepas dari beberapa kelemahan yang sudah dipaparkan, buku ini tetap penting dibaca untuk menambah wawasan dan horizon tentang ekonomi Islam. Dengan membaca buku ini paling tidak pembaca akan memahami konsep dan filosofi ekonomi Islam, sehingga setidaknya memberikan gambaran yang lebih luas pada pembaca bagaimana mestinya kehidupan ekonomi dibangun dan dikembangkan dengan berlandaskan nilai-nilai Islam. 